\title{
Long Noncoding RNA CCATI Functions as a Competing Endogenous RNA to Upregulate ITGA9 by Sponging MiR-296-3p in Melanoma [Retraction]
}

Fan J, Kang X, Zhao L, Zheng Y, Yang J, Li D. Cancer Manag Res. 2020;12:4699-4714.

The Editor and Publisher of Cancer Management and Research wish to retract the published article. Concerns were raised regarding the reliability of the miR-296-3p specific primers used to conduct the RT-qPCR experiments described in the study. Based on the primer details given in the article it is unlikely the results reported would have been obtained. The authors responded to our queries but were unable to provide a satisfactory explanation in regard to the RT-qPCR experimental concerns and could not provide satisfactory original data for their study. The Editor advised for the article to be retracted.

Our decision-making was informed by our policy on publishing ethics and integrity and the COPE guidelines on retraction.

The retracted article will remain online to maintain the scholarly record, but it will be digitally watermarked on each page as "Retracted".

\section{Publish your work in this journal}

Cancer Management and Research is an international, peer-reviewed open access journal focusing on cancer research and the optimal use of preventative and integrated treatment interventions to achieve improved outcomes, enhanced survival and quality of life for the cancer patient.
The manuscript management system is completely online and includes a very quick and fair peer-review system, which is all easy to use. Visit http://www.dovepress.com/testimonials.php to read real quotes from published authors. 